\title{
ANTIOXIDANT ACTIVITY, TOTAL PHENOLIC, AND FLAVONOID CONTENTS OF THE EXTRACT OF ENDOPHYTIC FUNGI DERIVED FROM TURMERIC (Curcuma longa) LEAVES
}

\author{
Eris Septiana $^{1 *)}$, Siti Irma Rahmawati ${ }^{1}$, Fauzia Nurul Izzati ${ }^{1}$, Partomuan \\ Simanjuntak ${ }^{1,2}$ \\ ${ }^{1}$ Laboratory of Natural Product Chemistry, Research Center for Biotechnology, LIPI, \\ JL. Raya Bogor KM 46 Cibinong, 16911, Indonesia \\ ${ }^{2}$ Faculty of Pharmacy, Pancasila University, JL. Srengseng Sawah, Jagakarsa, Jakarta \\ Selatan, 12640, Indonesia
}

Received June 21, 2019; Accepted November 22, 2019

\begin{abstract}
Air pollution can increase free radicals that may worsen some diseases. Antioxidants such as phenol and flavonoid compounds are known to counteract these free radicals. Long term use of synthetic antioxidants is known to cause bad effects on the body. Therefore, the necessity to search for natural antioxidants from plants and its endophytic microbes continues with the hope to obtain potential natural antioxidants with minimum side effects. The purpose of this study was to determine the antioxidant activity, total phenolic, and flavonoid contents of the extract of endophytic fungi which were derived from the Bogor-originated turmeric leaves via in vitro isolation. DPPH free radical scavenging method was used to determine in vitro antioxidant activity. The total phenolic and flavonoid contents assays were based on the Follin-Ciocalteu and aluminium chloride reagents, respectively. The extract of endophytic fungi of Bo.Ci.Cl.D1 and Bo.Ci.Cl.D2 showed antioxidant activity with $\mathrm{IC}_{50}$ value at 24.04 and $96.08 \mathrm{mg} / \mathrm{L}$, respectively. Total phenolic content of Bo.Ci.Cl.D1 and Bo.Ci.Cl.D2 extracts were 113.47 and $81.83 \mathrm{mg}$ gallic acid equivalent/g extract respectively. Total flavonoid content of Bo.Cl.D1 and Bo.Ci.Cl.D2 extracts were 41.79 and $38.50 \mathrm{mg}$ quercetin equivalent/g extract, respectively. Based on these assays, it could be concluded that the extract of Bo.Ci.Cl.D1 has better antioxidant activities than Bo.Ci.Cl.D2.
\end{abstract}

Keywords: antioxidant; Curcuma longa leaves; endophytic fungi; total flavonoid; total phenolic

\section{INTRODUCTION}

Heavy air pollution from motor vehicle fumes and cigarettes can increase the formation of free radicals in the body. Free radicals give impact on the pathogenesis of several diseases in humans due to the occurrence of oxidative cell stress (Sitorus et al., 2017). Under normal circumstances, radicals in the body will be eliminated by the body's natural defence mechanism. Materials that can counteract free radicals are called antioxidants. Antioxidants become so important nowadays because of their ability to reduce free radicals and inhibit lipid peroxidation so that they can protect the human body from attacks of several diseases caused by free radical reactions (Khani et al., 2017).

The use of synthetic antioxidants to prevent any damage caused by free radicals has been reported to give toxic side effects. Therefore, it is necessary to search for new sources of antioxidants, preferably from nature (Rico et al., 2013). One of the natural ingredients reported to have a high antioxidant activity is turmeric (Tanvir et 
al., 2017). Other than turmeric's rhizome, the leaves of the turmeric plant also reported showing antioxidant activity (Priya et al., 2012). The antioxidant ability of turmeric leaves extract is influenced by the content of phenolic compounds (Faujan et al., 2015), especially flavonoid compounds (Gruyal \& Rosario, 2013).

Within the tissue of turmeric leaves, the endophytic fungi can also be found. These endophytes are predicted to have the same antioxidant activity. Endophytic fungi were reported to have a high content of polyphenolic compounds (Yadav et al., 2014). Endophytic fungi are fungi that live in the host plant tissues without causing disease and form mutualism association (Nicoletti \& Fiorentino, 2015). Some endophytic fungi isolated from turmeric roots, stems, rhizomes, and tubers were reported to produce antioxidant compounds (Bustanussalam et al., 2015). This study aimed to examine the antioxidant activity, total phenol, and total flavonoid contents obtained from the in vitro extract of turmeric leaves endophytic fungi from Bogor using the DPPH free radical scavenging method.

\section{METHODS}

\section{Materials}

Endophytic fungi isolated from the leaves of some turmeric plants were obtained from the private garden of residents in sub-district of Tanah Sareal, Bogor. Two isolates were distinguished based on macroscopic, morphological characteristics. The identity of plant was confirmed at the Herbarium Bogoriense, Research Center for Biology, LIPI with number of certificate confirmation of 1145/IPH.1.02/If.8/VII/2012. Reagents and solvents used in this research: 2,2Diphenyl-1-picrylhydrazyl

(DPPH) (Sigma), ascorbic acid (Sigma), FollinCiocalteu (Merck) reagents, gallic acid (Sigma, >97\%), sodium carbonate (Merck, 99\%), quercetin (Sigma, >95\%), aluminum chloride (Merck, >98\%), sodium acetate (Merck, 99\%), methanol (Merck, for analysis 99\%), ethanol (Merck, for analysis 99\%), 96\% technical ethyl acetate, Potato Dextrose Agar (PDA) (Difco), Potato Dextrose Broth (PDB) (Difco), and aquades. The tools used in this study were rotary vacuum evaporator (Stuart), UV-vis spectrophotometer (Hitachi U-3900H), cuvette (Hellma), laminar air flow, analytical balance (Precisa 240A), water bath incubator (Grant), oven (Jouan), magnetic hotplate stirrer (Thermolyne), sonicator (Branson), shaker (Thermolyne), Buchner funnel, Erlenmeyer, microtube (Axygen), scale test tube, volumetric flask, micropipette (Eppendorf), micropropylene tip, autoclave (Tomy) and other glassware.

\section{Endophytic Fungi Fermentation and Extraction}

Isolation of endophytic fungi was performed using the surface sterilization method and grown on PDA, both later called by their isolate codes of Bo.Ci.Cl.D1 and Bo.Ci.Cl.D2, which were distinguished based on the morphological character macroscopically. Fungal colonies were rejuvenated on PDA and incubated for seven days at room temperature. The endophytic fungi isolates, which were seven days old, were then transferred into $100 \mathrm{~mL}$ of PDB in $250 \mathrm{~mL}$ Erlenmeyer flask. For making endophytic fungi growth curves, fermentation was carried out on a shaker $120 \mathrm{rpm}$ for 22 days at room temperature and then harvested every two days. The biomass obtained was then dried and weighed. Fermentation to obtain the extract was carried out on a shaker $120 \mathrm{rpm}$ for 14 days (stationary phase) at room temperature. After 14 days, the endophytic fungi filtrate and biomass were separated by filtration using sterile filter paper in a vacuum Buchner funnel. The filtrate was then extracted three times using ethyl acetate in the separated funnels and concentrated using a rotary evaporator until dried (Salini et al., 2015). 


\section{Antioxidant Activity}

The antioxidant activity assay was performed by free radical scavenging method (Tiwari et al., 2006) using DPPH with a modification on its wavelength of $517 \mathrm{~nm}$. The concentrations of the test solution were $5,10,25,50$, and $100 \mathrm{mg} / \mathrm{L}$. Ascorbic acid (vitamin C) as the standard was prepared in level concentrations of 1 , $3,5, \quad 7$, and $9 \mathrm{mg} / \mathrm{L}$, whereas the concentration of DPPH as control was 0.4 $\mathrm{mM}$. All samples, control, and standard solutions were incubated at $37{ }^{\circ} \mathrm{C}$ for 30 minutes for then measured at $517 \mathrm{~nm}$. Antioxidant activity was obtained using the equation below and $\mathrm{IC}_{50}$ value, a number that shows the concentration of test samples capability to inhibit the oxidation process by $50 \%$, which was obtained by making a linear curve between the concentration of the test solution ( $\mathrm{x}$ axis) and antioxidant activity (y-axis).

$$
\begin{aligned}
\% \text { Inhibition } & =(\mathrm{A}-\mathrm{B}) / \mathrm{A} \times 100 \% \\
\text { Note: } \mathrm{A} & =\text { blank absorption } \\
\mathrm{B} & =\text { absorption of test material }
\end{aligned}
$$

\section{Total Phenolic and Flavonoid Contents}

The concentration of ethyl acetate extract from isolated endophytic fungi in ethanol was $1000 \mu \mathrm{g} / \mathrm{mL}$. The total phenolic assay was started by making the standard solution of gallic acid in distilled water with concentration series of 20;40; $60 ; 80 ; 100$; and $120 \mathrm{mg} / \mathrm{L}$ to make the standard curve of gallic acid. A total of 1 $\mathrm{mL}$ of extract (test sample) and gallic acid (standard) were put into separate test tubes and later $0.1 \mathrm{~mL}$ of Follin-Ciocalteu reagent and $0.9 \mathrm{~mL}$ of distilled water were added into each tube. Each mixture was then incubated at room temperature for 5 minutes. $1 \mathrm{~mL}$ of sodium carbonate $7 \%$ and $0.4 \mathrm{~mL}$ of distilled water were added into the test tube and incubated for 30 minutes at room temperature. The uptake of the mixture was measured at $765 \mathrm{~nm}$. Total phenolic content is expressed as $\mathrm{mg}$ gallic acid equivalent to per gram of dried extract (mg GAE/g dry weight) (Pekal \& Pyrzynska, 2014).

The standard quercetin solution in ethanol with concentration series of 10 ; $15 ; 20 ; 25 ; 30 ; 35$; and $40 \mathrm{mg} / \mathrm{L}$ was measured to make the standard curve of quercetin in the assay of total flavonoid content. $500 \mu \mathrm{L}$ of extract (test sample), quercetin (standard), and ethanol (blank) were put into separate test tubes and later $1.5 \mathrm{~mL}$ of ethanol was added into each tube. Then, $0.1 \mathrm{~mL}$ of aluminum chloride solution $(0.1 \mathrm{~g} / \mathrm{mL}), 0.1 \mathrm{~mL}$ of sodium acetate $(1 \mathrm{M})$ and $2.8 \mathrm{~mL}$ of distilled water were also added. Each mixture was then incubated for 30 minutes at room temperature and then measured at $415 \mathrm{~nm}$. Total flavonoid content is expressed as $\mathrm{mg}$ quercetin equivalent to per gram of dried extract (mg QE/g dry weight) (Kaur \& Singh, 2015).

\section{RESULTS AND DISCUSSION Endophytic Fungi Fermentation and Extraction}

Fermentation was done by shaken culture fermentation method to maintain aeration and agitation. Aeration is needed to supply endophytic fungi oxygen while agitation or stirring aims to increase oxygen supply in the medium as well as to maintain temperature homogeneity (Kumala \& Pratiwi, 2014). The isolates were spherical when grown in liquid fermentation media and the color of mycelium was identical to the color when grown on agar media. Bo.Ci.Cl.D1 isolate mycelium was black, while Bo.Ci.Cl.D2 isolate was yellowish pink. The harvesting of endophytic fungi was carried out during the stationary growth phase (Figure 1) because, in general, fungi will produce secondary metabolites during this phase (Basha et al., 2012). Secondary metabolite compounds will be released into fermentation media. Therefore, the filtrate extract of endophytic fungi contains more secondary metabolites in terms of weight than the mycelia or biomass (Bustanussalam et al., 2015). 


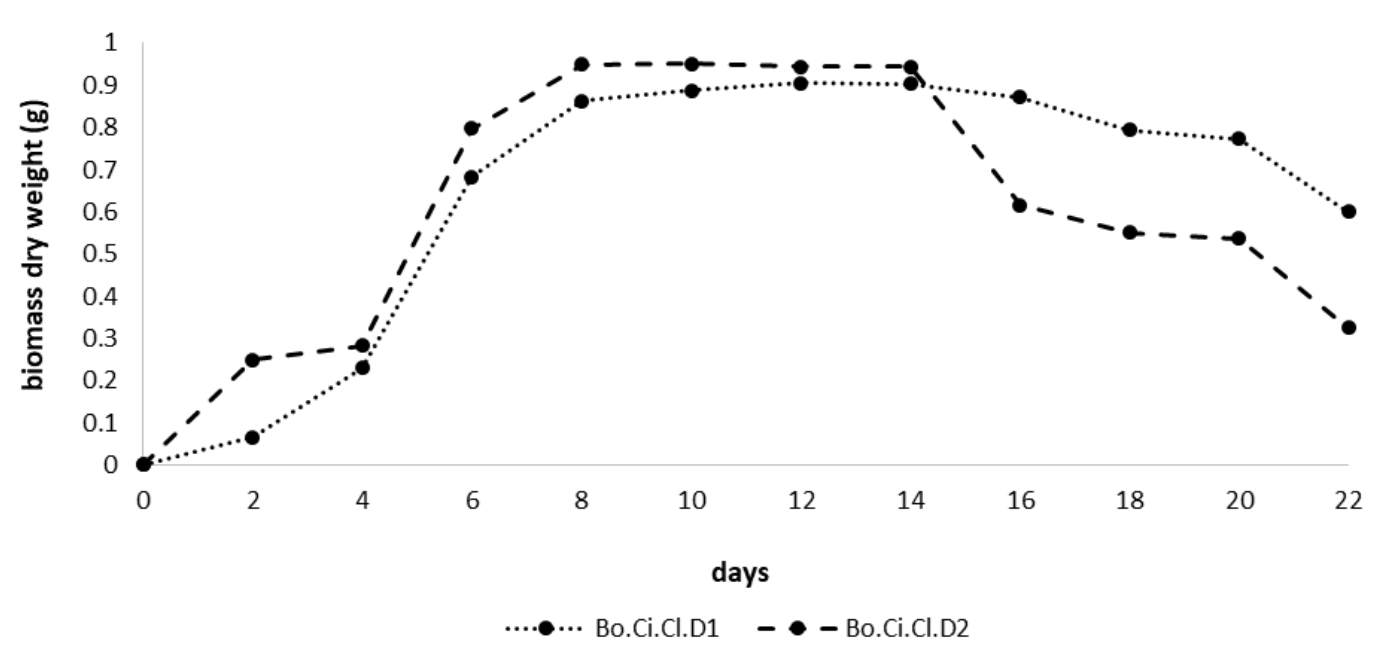

Figure 1. Growth curve of endophytic fungi derived from turmeric leaves of isolate 1 (Bo.Ci.Cl.D1) and isolate 2 (Bo.Ci.C1.D2)

\section{Antioxidant Activity}

The assay of antioxidant activity showed that both ethyl acetate extract of the filtrate isolates have antioxidant activity (Table I). The test results also showed that both extracts have an inhibition above $50 \%$ at the concentration of the test material of $100 \mathrm{mg} / \mathrm{L}$. The extract of Bo.Ci.Cl.D1 isolate had a lower $\mathrm{IC}_{50}$ value compared to the extract of Bo.Ci.Cl.D2 isolate; hence, the extract of Bo.Ci.Cl.D1 isolate has a better antioxidant activity (Table I).

The strength of antioxidant activity are categorised into very active categories ( $\mathrm{IC}_{50}<10 \mathrm{mg} / \mathrm{L}$ ), active ( $\mathrm{IC}_{50}<100 \mathrm{mg} / \mathrm{L}$ ), and inactive ( $\mathrm{IC}_{50}>100 \mathrm{mg} / \mathrm{L}$ ) (Minami et al., 1994). The antioxidant activity of both extracts are categorised as active since the $\mathrm{IC}_{50}$ value of both isolates were $<100$ $\mathrm{mg} / \mathrm{L}$. However, both showed lower activity compared to ascorbic acid as the positive control with an $\mathrm{IC}_{50}$ value of 3.88 $\mathrm{mg} / \mathrm{L}$ which is in the very active category (Minami et al., 1994). The extract of endophytic fungi of Bo.Ci.Cl.D1 showed a better antioxidant activity compared to the ethanol extract of turmeric leaves, obtained from the previous study conducted by Faujan et al. (2015), which $\mathrm{IC}_{50}$ value was $85 \mathrm{mg} / \mathrm{L}$.

DPPH scavenging method is commonly used in antioxidant studies. The antioxidant effect in the DPPH free radical scavenging method occurs because of the ability of a compound to donate hydrogen (Babu et al., 2013). The extract of endophytic fungi isolated from Rhodiola crenulata, $R$. angusta, and $R$. sachalinensis plants were reported to have good antioxidant abilities (Cui et al., 2015). Antioxidant activity of Bo.Ci.Cl.D1 extract showed a better activity with $\mathrm{IC}_{50}$ value of $24.04 \mathrm{mg} / \mathrm{L}$, compared with the activity of endophytic fungi extract from turmeric plant rhizomes with the $\mathrm{IC}_{50}$ value of $32.28 \mathrm{mg} / \mathrm{L}$, reported in the previous study (Septiana et al., 2017). 
Table I. Antioxidant activity from endophytic fungi extracts derived from turmeric leaves

\begin{tabular}{|c|c|c|c|c|}
\hline No & Sample code & $\begin{array}{l}\text { Concentration } \\
(\mathrm{mg} / \mathrm{L})\end{array}$ & $\begin{array}{l}\text { Inhibition } \\
(\%) \pm \mathrm{SD}\end{array}$ & $\begin{array}{c}\mathrm{IC}_{50} \\
(\mathrm{mg} / \mathrm{L}) \pm \mathrm{SD}\end{array}$ \\
\hline \multirow[t]{5}{*}{1} & Bo.Ci.Cl.D1 & 5 & $19.36 \pm 0.18$ & \\
\hline & & 10 & $31.28 \pm 0.36$ & \\
\hline & & 25 & $50.83 \pm 0.27$ & $24.04 \pm 0.11$ \\
\hline & & 50 & $73.08 \pm 0.54$ & \\
\hline & & 100 & $76.54 \pm 0.18$ & \\
\hline \multirow[t]{5}{*}{2} & Bo.Ci.Cl.D2 & 5 & $1.54 \pm 0.36$ & \\
\hline & & 10 & $1.60 \pm 0.63$ & \\
\hline & & 25 & $12.11 \pm 0.27$ & $96.08 \pm 0.06$ \\
\hline & & 50 & $28.78 \pm 0.09$ & \\
\hline & & 100 & $50.83 \pm 0.09$ & \\
\hline \multirow[t]{5}{*}{3} & Vit. C & 1 & $22.64 \pm 2.67$ & \\
\hline & & 3 & $41.73 \pm 5.11$ & \\
\hline & & 5 & $69.60 \pm 1.07$ & $3.88 \pm 0.14$ \\
\hline & & 7 & $90.35 \pm 0.53$ & \\
\hline & & 9 & $93.75 \pm 0.91$ & \\
\hline
\end{tabular}

Table II. Total phenolic and flavonoid contents of endophytic fungi extracts derived from turmeric leaves

\begin{tabular}{cccc}
\hline No. & Sample code & $\begin{array}{c}\text { Total Phenolic Content (mg gallic } \\
\text { acid equivalent/g dry weight) } \pm \text { SD }\end{array}$ & $\begin{array}{c}\text { Total Flavonoid Content (mg } \\
\text { quercetin equivalent/g dry weight) } \\
\pm S D\end{array}$ \\
\hline 1 & Bo.Ci.Cl.D1 & $113.47 \pm 0.25$ & $41.79 \pm 0.07$ \\
\hline 2 & Bo.Ci.Cl.D2 & $81.83 \pm 0.14$ & $38.50 \pm 0.13$ \\
\hline
\end{tabular}

\section{Total Phenolic and Flavonoid Contents}

The ability of endophytic fungi extract to give positive results in the antioxidant activity assay is related to the composition of its chemical compounds. Some of the chemical compounds in endophytic fungi that are active as antioxidants are phenols and flavonoids. Phenol and flavonoid compounds, contained in some endophytic fungi from plants Calotropis procera, are acting as antioxidants (Nagda et al., 2017).

The phenolic and flavonoid contents of Bo.Ci.Cl.D1 extract were higher than Bo.Ci.Cl.D2 (Table II). The result supported the antioxidant activity result, in which Bo.Ci.Cl.D1 also showed better activity than Bo.Ci.Cl.D2 (Table I). The results of this study are in line with previous studies which stated that antioxidant activity has a very close relationship with the levels of phenols and total flavonoids. The higher content of total phenols and flavonoids, the higher the antioxidant activity (Esmaelli et al., 2015).
The phenols (in mg GAE/g DW) and flavonoids (in $\mathrm{mg} \mathrm{QE} / \mathrm{g} \mathrm{DW}$ ) in an endophytic fungi extract can be divided into several levels. Endophytic fungi extract with total phenol content of $<20$ $\mathrm{mg} / \mathrm{g}$ are categorised in the low category, $20-40 \mathrm{mg} / \mathrm{g}$ in the moderate category, and $>40 \mathrm{mg} / \mathrm{g}$ in the high category. Endophytic fungi extract with a total flavonoid content of $<15 \mathrm{mg} / \mathrm{g}$ are in the low category, 15-30 $\mathrm{mg} / \mathrm{g}$ in the moderate category, and $>30$ $\mathrm{mg} / \mathrm{g}$ in the high category (Zohri et al., 2017). Therefore, the total phenolic and flavonoid contents of the two extracts in this study could be categorised as high due to their total phenolic contents which was $>40 \mathrm{mg} / \mathrm{g}$ and flavonoid contents which was $>30 \mathrm{mg} / \mathrm{g}$ (Table II).

The phenolic contents of both endophytic fungi Bo.Ci.Cl.D1 and Bo.Ci.Cl.D2 extracts are higher than the phenolic contents of turmeric leaves in ethanol extract reported in the previous study which was only $8.86 \mathrm{mg}$ GAE/g DW (Faujan et al., 2015). However, the flavonoid contents of both extracts were 
still lower than those of turmeric leaves in ethanol extract from the same study, which reported to contain $141.09 \mathrm{mg}$ QE/g DW (Gruyal \& Rosario, 2013). The mechanism of flavonoids as antioxidants can occur through several mechanisms. One possible mechanism is the ability of flavonoids to bind free radical immediately by donating a hydrogen atom or transfer a single electron (Prochazkova et al., 2011). In this study, each extract showed different ability to reduce free radicals, despite being originated from the same part of the plant. The different antioxidant abilities are caused by the fact that each endophyte may produce different compounds with the same function or different amounts depending on their interaction with the host plant (Selim et al., 2012).

\section{CONCLUSION}

The ethyl acetate extract of endophytic fungus of Bo.Ci.Cl.D1 from turmeric leaves cultivated in Bogor showed a better antioxidant activity and higher total phenolic and flavonoid contents compared to Bo.Ci.Cl.D2.

\section{ACKNOWLEDGEMENT}

The author would like to thank the Indonesian Institute of Sciences for financing this research through the 2017 DIPA research fund.

\section{REFERENCES}

Babu, D., Gurumurthy, P., Borra, S.K., Cherian, K.M. 2013. Antioxidant and Free Radical Scavenging Activity of Triphala Determined by Using Different In Vitro Models. Journal of Medicinal Plants Research, 7(39), 2898-2905.

Basha, N.S., Ogbaghebriel, A., Yemane, K., Zenebe, M. 2012. Isolation and Screening of Endophytic Fungi from Eritrean Traditional Medicinal Plant Terminalia brownie Leaves for Antimicrobial Activity. International Journal of Green Pharmacy, 6(1), 40-44.
Bustanussalam, Rachman, F., Septiana, E., Lekatompessy, S.J.R., Widowati, T., Sukiman, H.I., Simanjuntak, P. 2015. Screening for Endophytic Fungi from Turmeric Plant (Curcuna longa L.) of Sukabumi and Cibinong with Potency as Antioxidant Compounds Producer. Pakistan Journal of Biological Sciences, 18(1), 42-45.

Cui, J.L., Guo, T.T., Ren, Z.X., Zhang, N.S., Wang, M.L. 2015. Diversity and Antioxidant Activity of Culturable Endophytic Fungi from Alpine Plants of Rhodiola crenulata, $R$. angusta, and $R$. sachalinensis. PLoS One, 10(3), e0118204.

Esmaelli, A.K., Taha, R.M., Mohajer, S., Banisalam, B. 2015. Antioxidant Activity and Total Phenolic and Flavonoid Content of Various Solvent Extracts from In Vivo and In Vitro Grown Trifolium pretense L. (Red Clover). BioMed Research International, 643285:11.

Faujan, N.H., Rahim, Z.A., Rehan, M.M., Ahmad, F.B.H. 2015. Comparative Analysis of Phenolic Content and Antioxidative Activities of Eight Malaysian Traditional Vegetables. Malaysian Journal of Analytical Sciences, 19(3), 611-624.

Gruyal, G.A., Rosario, R.R. 2013. Phytochemical Profiles and Quantifications of Flavonoid Contents of Selected Herbs in Cantilan, Surigao Del Sur Philipines. SDSSU Multidisiplin Research Journal, 1(2), 126-133.

Kaur, J., Singh, S., 2015. Effect of Sprouting on In Vitro Antioxidant Potential of Some Varieties of Chickpea Seeds (Cicer arietinum Linn.). Asian Journal of Pharmaceutical and Clinical Research, 8(6), 265-268.

Khani, M., Motamedi, P., Dehkhoda, M.R., Nikukheslat, S.D., Karimi, P. 2017. Effect of Thyme Extract 
Supplementation on Lipid Peroxidation, Antioxidant Capacity, PGC-1 $\alpha$ Content and Endurance Exercise Performance in Rats. Journal of the International Society of Sports Nutrition, 14:11.

Kumala, S., Pratiwi, A.P. 2014. Efek Antimikroba dari Kapang Endofit Ranting Tanaman Biduri. Jurnal Farmasi Indonesia, 7(2), 111-120.

Minami, H., Kinoshita, M., Fukuyama, Y., Kodama, M., Yoshizawa, T., Sugiura, M., Nakagawa, K., Tago, H. 1994. Antioxidant Xanthones from Garcinia subelliptica. Phytochemistry, 36(2), 501-506.

Nagda, V., Gajbhiye, A., Kumar, D. 2017. Isolation and Charachterization of Endophytic Fungi from Calotropis procera for Their Antioxidant Activity. Asian Journal of Pharmaceutical and Clinical Research, 10(3), 254-258.

Nicoletti, R., Fiorentino, A. 2015. Plant Bioactive Metabolites and Drugs Produced by Endophytic Fungi of Spermatophyta. Agriculture, 5(4), 918-970.

Pekal, A., Pyrzynska, K. 2014. Evaluation of Aluminium Complexation Reaction from Flavonoid Content Assay. Food Analytical Methods, 7(9), 1776-1782.

Priya, R., Prathapan, A., Raghu, K.G., Menon, A.N. 2012. Chemical Composition and In Vitro Antioxidative Potential of Essential Oil Isolated from Curcuma longa L. Leaves. Asian Pacific Journal of Tropical Biomedicine, 2(2), S695S699.

Prochazkova, D., Bousova, I., Wilhelmova, N. 2011. Antioxidant and Prooxidant Properties of Flavonoids. Fitoterapia, 82(4), 513-523.

Rico, M., Sanchez, I., Trujillo, C., Perez, N. 2013. Screening of the Antioxidant Properties of Crude
Extracts of Six Selected Plant Species from the Canary Island (Spain). Journal of Applied Botany and Food Quality, 86(1), 217-220.

Salini, G., Madhusoodhanan, A., Joseph, A., Mohan, A., Navya, R.K., Nair, V.V. 2015. Antibacterial and Antioxidant Potential of Endophytic Fungi Isolated from Mangroves. Der Pharmacia Lettre, 7(12), 53-57.

Selim, S., El Alfy, S., Al-Ruwaili, M., Abdo, A., Al Jaouni, S. 2012. Susceptibility of ImipenemResistant Pseudomonas aeruginosa to Flavonoid Glycosides of Date Palm (Phoenix dactylifera L.) Tamar Growing in Al Madinah, Saudi Arabia. Affrican Journal of Biotechnology, 11(2), 416-422.

Septiana, E., Bustanussalam, Rachman, F., Hapsari, Y., Simanjuntak, P. 2017. Potensi Ekstrak Kapang Endofit Asal Rimpang Kunyit Sebagai Antimalaria dan Antioksidan. Jurnal Kefarmasian Indonesia, 7(1), 1-9.

Sitorus, M.S., Anggraini, D.R., Hidayat. 2017. Decreasing Free Radicals Level on High Risk Person after Vitamin C and E Supplement Treatment. IOP Conference Series: Materials Science and Engineering, 180(1).

Tanvir, E.M., Hossen, M.S., Hossain, M.F., Afroz, R., Gan, S.H., Khalil, M.I., Karim, N. 2017. Antioxidant Properties of Popular Turmeric (Curcuma longa) Varieties from Bangladesh. Journal of Food Quality, 8471785.

Tiwari, V., Shanker, R., Srivastava, J., Vanker, P.S. 2006. Change in Antioxidant Activity of SpicesTurmeric and Ginger on Heat Treatment. Electronic Journal of Environmental, Agricultural and Food Chemistry, 5(2), 1313-1317. 
Yadav, M., Yadav, A., Yadav, J.P. 2014.

In Vitro Antioxidant Activity and

Total Phenolic Content of

Endophytic Fungi Isolated from

Eugenia jambolana Lam. Asian

Pacific Journal of Tropical Medicine, 7(1), S256-S261.

Zohri, A.A., Moharram, A.M., El-Ghani, O.A.A. 2017. Antioxidant Potentialities of Some Strains Belonging to Endophytic, Entomophatogenic and Saprophytic Fungi. European Journal of Biological Research, 7(1), 76-85. 